\title{
THE MANAGEMENT OF, AND FISHERY FOR, AMERICAN EEL ELVERS IN THE MARITIME PROVINCES, CANADA.
}

\author{
B.M. JESSOP \\ Biological Sciences Branch, Department of Fisheries and Oceans, \\ P.O. Box 550, Halifax, Nova Scotia, B3J 2S7, Canada.
}

\begin{abstract}
The fishery for American eel, Anguilla rostrata, elvers in the Scotia-Fundy area of Atlantic Canada has, since inception in 1989, increased catches from $26 \mathrm{~kg}$ to about $3000 \mathrm{~kg}$ in 1996. Development of the fishery has been tightly controlled with nine licenses presently (1996) issued, three of which are restricted to aquaculture use. No elver fishery is permitted in rivers in which an active fishery for larger eels exists, each license has a quota of up to 1 ton, with a limit of $300 \mathrm{~kg}$ from any given river, and records of daily catch and fishing effort, by gear type, are now required for each river fished.
\end{abstract}

Elver catches and CPUE vary geographically, being highest along the south shore and lower Bay of Fundy areas of Nova Scotia, moderately high along the lower Bay of Fundy, New Brunswick, and lowest along the eastern shore of Nova Scotia and upper Bay of Fundy areas (Minas Basin and Chignecto Bay). In all areas but the eastern shore of Nova Scotia, commercial quantities of elvers first arrive in April. Elver catch peaks during May, then declines through June with small (less than $1 \%$ of total) catches occurring in some areas during early July. Geographic differences in elver catches and run timing may be linked to oceanographic current patterns, particularly the southwestward flow of the Nova Scotia Current along the Atlantic coast and the counter-clockwise flow around the Bay of Fundy, and differences in the timing of rising river water temperatures during spring.

Elver run size was not proportional to river size (drainage area) for two rivers from different geographic areas nor was elver fishery catch-per-unit-fishing effort proportional to river drainage area, perhaps because of geographic differences in elver density.

Key-words : fishery, Anguilla rostrata, elvers, Atlantic Canada.

\section{LA GESTION DE, ET PÊCHE POUR, LES CIVELLES DE L'ANGUILLE D'AMÉRIQUE DANS LES PROVINCES MARITIMES DU CANADA.}

\section{RÉSUMÉ}

La pêche des civelles de l'anguille d'Amérique, Anguilla rostrata, dans la région de Scotia-Fundy, au Canada atlantique, a, depuis ses débuts en 1989, connu une hausse des captures, qui de $26 \mathrm{~kg}$ sont passées à environ $3000 \mathrm{~kg}$ en 1996. Le développement de cette pêche a été géré de façon stricte. On compte actuellement neuf permis en 1996 , dont trois sont réservés à l'industrie de l'aquaculture. II est interdit de pêcher des civelles dans des rivières où est pratiquée activement une pêche des plus grosses anguilles. Par ailleurs, chaque permis est assorti d'un quota maximal d'une tonne, la limite par rivière étant de $300 \mathrm{~kg}$, et les pêcheurs doivent fournir des relevés de leurs prises quotidiennes et de leur effort de pêche, par type d'engin, dans chaque rivière où ils ont pêché. 
Les prises de civelles et les PUE varient selon la région. Elles sont les plus élevées le long de la côte sud et de la partie inférieure de la baie de Fundy en Nouvelle-Écosse, assez élevées le long de la partie inférieure de la baie de Fundy au Nouveau-Brunswick et plus basses le long de la côte est de la Nouvelle-Écosse et de la partie supérieure de la baie de Fundy (bassin des Mines et baie Chignecto). Sauf sur la côte est de la NouvelleÉcosse, les civelles commencent à arriver en quantités commerciales dans tous les secteurs en avril. Les prises culminent en mai, puis diminuent en juin. Des petites quantités (moins de $1 \%$ du total) de civelles sont capturées dans certains secteurs au début de juillet. Les variations géographiques dans les prises et les remontées peuvent être reliées aux régimes de courants océaniques, particulièrement au courant de la Nouvelle-Écosse en direction sud-ouest, le long de la côte atlantique, et au courant rotatif de droite à gauche le long de la baie de Fundy, ainsi qu'à des différences dans la période d'élévation des températures de l'eau des rivières au printemps.

L'importance des remontées des civelles n'était pas proportionnelle à la taille de la rivière (zone de drainage), pour deux rivières de différentes zones géographiques, de même que les prises par unité d'effort de pêche de la pêche aux civelles n'étaient pas proportionnelles à la zone de drainage de la rivière, peut-être en raison de différences géographiques dans la densité des civelles.

Mots-clés : pêche, Anguilla rostrata, civelle, Canada atlantique.

\section{INTRODUCTION}

High demand for, and continuing shortages of, elvers of Anguilla japonica in Asia and $A$. anguilla in Europe for aquaculture has generated profitable export markets for elvers of $A$. rostrata from North America to, primarily, Asia. Fisheries for American eel elvers have occurred with varying, market-driven intensity in several Atlantic coast U.S. states since the early 1970s (FAHAY, 1978 ; GOUSSET, 1992). Since 1989, elver fisheries have progressively developed in the Bay of Fundy and Atlantic coastal areas of New Brunswick (N.B.) and Nova Scotia (N.S.), termed the Scotia-Fundy area, and are presently the only such fisheries occurring in Atlantic Canada (JESSOP, $1995 ; 1996 a$ ).

\section{ELVER FISHERY MANAGEMENT}

In 1989, the first two licenses were issued to fish experimentally for American eel elvers in the lower reaches of the Bay of Fundy in Nova Scotia and New Brunswick. As of 1996, a total of nine licenses have been issued, covering all of the Scotia-Fundy area coastline except sections of southwestern Nova Scotia, the north shore of Minas Basin in the Upper Bay of Fundy, and the southwest portion of Cape Breton Island (Figure 1).

The licenses issued and territories fished can be conveniently grouped into seven geographic areas : 1) the lower Bay of Fundy, N.B. (LBFNB), extending from the Maine border to the Saint John River ; 2) Chignecto Bay (CHIGNECTO), extending from the Saint John River through Chignecto Bay to Cape Chignecto ; 3) Minas Basin (MINAS), from Cape Chignecto through Minas Basin to, and including, Kings County, N.S. ; 4) lower Bay of Fundy, N.S. (LBFNS), comprising Annapolis and Digby Counties, N.S. ; 5) South Shore, N.S. (SSNS), extending from Queens County, N.S. to Halifax Harbour ; 6) Eastern Shore, N.S. (ESNS), covering north of Halifax Harbour to the Canso Causeway ; 7) Eastern Cape Breton (ECB), comprising the Atlantic coast of Cape Breton from the Canso Causeway to Cape North, which can presently be ignored because no elvers have yet been caught there. 


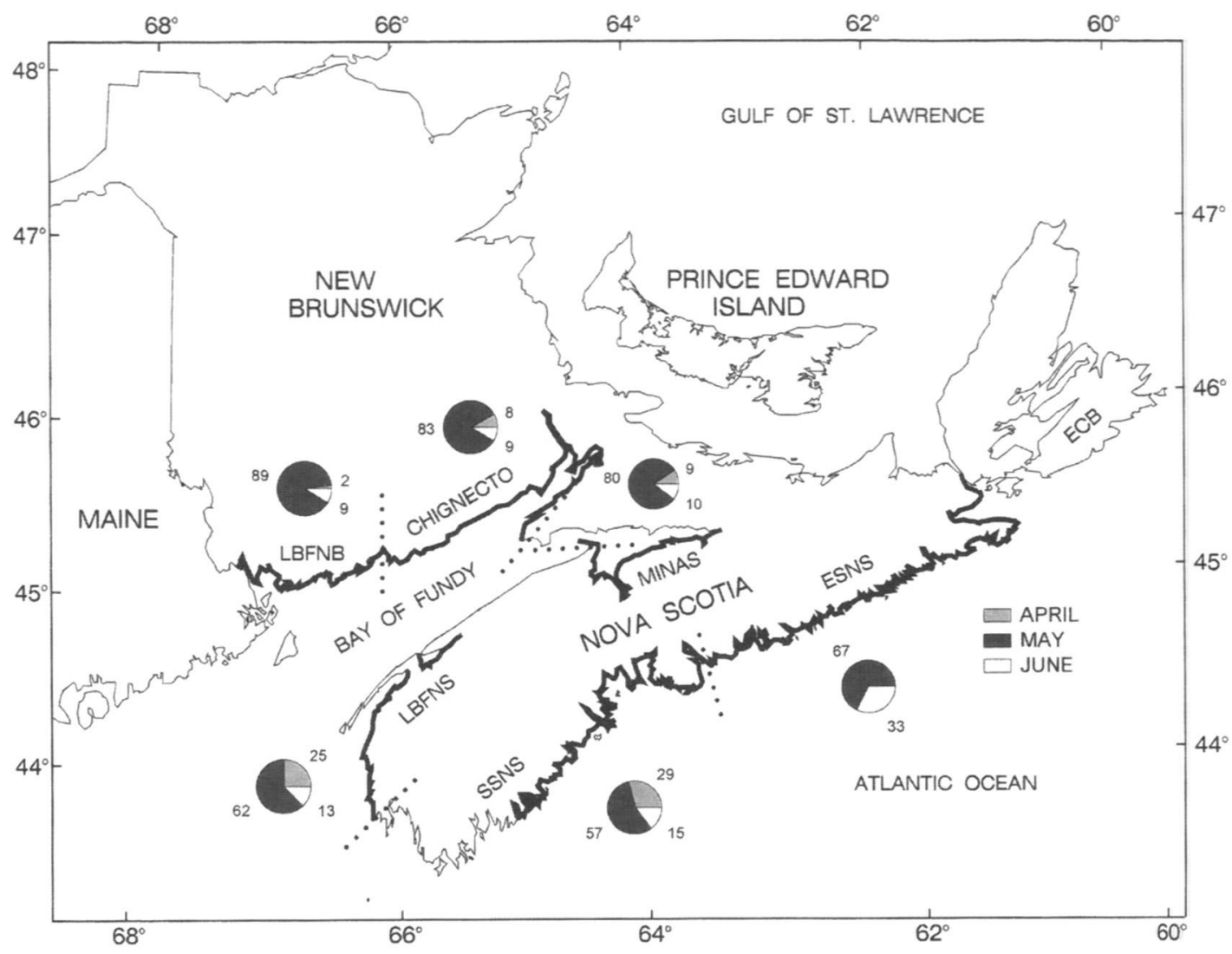

Figure 1

Map of the Maritime Provinces with boundaries and extent (indicated by thickened coastline) of the geographic areas where fisheries occur for American eel elvers, 1996 (LBFNB - lower Bay of Fundy, N.B. ; CHIGNECTO - upper Bay of Fundy, N.B. and Chignecto Bay ; LBFNS - lower Bay of Fundy, N.S. ; SSNS southern Atlantic coast of N.S. ; ESNS - eastern Atlantic coast of N.S. ; ECB eastern Cape Breton Island). The pie charts indicate the weighted mean monthly percentages of total catch $(\mathrm{kg})$ of American eel elvers, by geographic area, for the years 1994 to 1996 (except CHIGNECTO and ESNS areas which have data only for 1995 and 1996).

Figure 1

Carte des Provinces Maritimes illustrant les limites et l'étendue (épaisseur du trait de ligne de côte) des régions géographiques où a été pratiquée la pêche de la civelle en 1996 (LBFNB = partie néo-brunswickoise de l'entrée de la baie de Fundy) ; CHIGNECTO = partie néo-brunswickoise du fond de la baie de Fundy et baie de Chignecto ; LBFNS = partie néo-écossaise du fond de la baie de Fundy ; SSNS = côte atlantique sud de la Nouvelle-Écosse ; ESNS = côte atlantique est de la Nouvelle-Écosse ; ECB = est de l'île du Cap-Breton). Le diagramme circulaire indique les pourcentages mensuels moyens pondérés des prises totales $(\mathrm{kg})$ de civelles, par région géographique, de 1994 à 1996 (sauf en ce qui concerne les régions de CHIGNECTO et de l'ESNS, pour lesquelles les données se limitent à 1995 et 1996). 
Experimental licenses are issued for a specific purpose, have no guarantee of renewal, and may contain a variety of restrictions. Present restrictions for each license include : 1) a defined geographic area with approval to fish only specific rivers (from 5-18 in number) in that area ; 2) no elver fishery in rivers in which an existing fishery occurs for larger eels ; 3 ) limits on the type of fishing gear permitted (generally dip net but including various types of trap, fyke, and push nets) and quantity of gear, other than dip net ; 4) a requirement for live release of bycatch of other species ; 5) an overall quota of, usually, one tonne, with a limit of $300 \mathrm{~kg}$ on the quantity from any single river (annual quota extensions of up to $300 \mathrm{~kg}$ may be granted in years in which the quota is quickly reached) ; 6) permission for the sale of elvers (fishery regulations otherwise prohibit catch and retention of eels less than $20 \mathrm{~cm}$ long) except for three licenses where catch is restricted to aquaculture use ; 7) a requirement to submit, monthly during the fishing season, a record of daily catch $(\mathrm{kg})$ for each river (fishing effort $(\mathrm{h})$, by gear type, is also required as of 1996). In 1997, four experimental elver fishing licenses were converted to regular licenses with the objective of providing the more established fishers with some assurance of continuity to the fishery, and an industry-funded, independent quota monitoring system was implemented. Once issued, a regular license is annually renewable upon application and is restricted only by the provisions allowed under the Canada Fishery General Regulations and Maritime Provinces Fishery Regulations governing such topics as fishing seasons, locations, quotas, gear types and usage, bycatch provisions and catch and effort reporting. Eligibility criteria for new licenses to fish presently unallocated territories have been developed which accommodate native fisheries and needs of the aquaculture industry.

The restricted issue of elver fishing licenses and the large geographic area covered by each license, coupled with the provisions of the Canadian Privacy Act and Access to Information Act, prevent public presentation of the detailed geographic analysis of elver catches because of the possible linkage of specific catch values to an individual fisher thereby revealing personal economic information. Subsequent discussions of the fishery will be constrained by this fact but this analysis is fully consistent with a detailed analysis of the fishery catch and effort data.

\section{COMMERCIAL FISHERY}

The elver fishery in the Scotia-Fundy area is primarily a dip-net fishery, although Sheldon elver traps (SHELDON, 1974), fyke nets, pots, and a push net are also used depending upon the geomorphologic and discharge conditions within the tidal and near head-of-tide fishing zones of each river mouth. Elver catches increased slowly from $26 \mathrm{~kg}$ to $227 \mathrm{~kg}$ between 1989 and 1992 then approximately doubled annually until 1995, when the catch totalled $3238 \mathrm{~kg}$, then declined about $12 \%$ to $2862 \mathrm{~kg}$ in 1996 (Table 1). The recently high, but annually and seasonally volatile, price of elvers (mean of about $\$ 540$ Canadian per $\mathrm{kg}$ in 1996) valued the 1996 fishery at 1.5 million dollars. In the early years, the low catches derive from just two or three fishers who were developing their knowledge of the elver runs to various rivers in their license area, their skills in catching, handling, and shipping elvers, and establishing markets for their catch. As fisher skills and knowledge improved and elver fishery licenses for new geographic areas were granted, the total catch increased. The fishery is maturing in the sense that no additional licenses will be issued for the foreseeable future, the present experimental fishing permits are being converted to regular licenses, and the fishers have acquired substantial fishing and marketing skills.

Elver fishers followed a similar approach in all areas. During the early part of the fishing season, rivers permitted to be fished were checked periodically for elvers. When their presence was confirmed, more regular fishing began. Fishing typically occurred nightly during the elver run, with fishing intensity usually dependent upon elver density. Heavy rainfall, cold weather periods, and unfavorable (declining or low) evening tides often 


\section{Table I}

Annual catch $(\mathrm{kg})$ of American eel elvers in the Scotia-Fundy area, by province, and number of licenses issued from 1989 to 1996.

\section{Tableau I}

Prises annuelles (kg) de civelles dans le secteur de Scotia-Fundy, par province, et nombre de permis délivrés de 1989 à 1996.

\begin{tabular}{ccccc}
\hline Year & $\begin{array}{c}\text { New } \\
\text { Brunswick }\end{array}$ & $\begin{array}{c}\text { Nova } \\
\text { Scotia }\end{array}$ & $\begin{array}{c}\text { Total } \\
\text { catch }\end{array}$ & $\begin{array}{c}\text { Number of } \\
\text { licenses }\end{array}$ \\
\hline 1989 & 0 & 26 & 26 & 2 \\
1990 & 132 & 42 & 174 & 2 \\
1991 & 65 & 0 & 65 & 2 \\
1992 & 227 & 0 & 227 & 3 \\
1993 & 534 & 179 & 713 & 3 \\
1994 & 650 & 924 & 1574 & 4 \\
1995 & 549 & 2689 & 3238 & 7 \\
1996 & 449 & 2413 & 2862 & 9 \\
\hline
\end{tabular}

caused temporary cessation of fishing. Fishing ceased when the fishers judged the catchper-hour uneconomic. Near maximal economic fishing pressure may be applied in most fishing territories because the high value of elvers provides incentive to achieve quotas even at relatively low catch rates. Consequently, the recent patterns in annual and geographic catch variability may reflect underlying biological phenomena.

\section{CATCH VARIABILITY}

Elver catches vary annually and seasonally within and among the six geographic regions where fishing presently occurs. Between 1994 and 1996 (the years with the highest annual catches and a maturing fishery in most areas), catches varied among regions up to about eight-fold. Catches were consistently highest along the South Shore and lower Bay of Fundy, N.S., moderately high in the lower Bay of Fundy, N.B., lower along the Eastern Shore, N.S., and lowest (and similar) in the upper Bay of Fundy areas of Chignecto Bay and Minas Basin (Figure 1).

Within a geographic region, the elver catch depends on elver abundance, fishing effort, and elver catchability (availability, fishing efficiency) and the distribution of elvers through the run. Fishing effort (all gear types) in 1996 varied among regions from about $430 \mathrm{hrs}$ to almost $8900 \mathrm{hrs}$ (mode $1100 \mathrm{hrs}$ ) distributed throughout the elver run roughly in proportion to perceived elver abundance by the fisher. Since catch efficiencies vary among gear types and the mix of gear types varies among regions, further analysis will deal only with the most widely used gear, the dip net, which was responsible for $66 \%$ of the total 1996 catch. Dip-net fishing efficiency has been assumed to be constant among fishers and sites, which are small-to-medium sized rivers. Moderate fishing effort, resulting in little or no catch, was expended in all areas checking for the start and possible late continuation of the elver runs to individual rivers, but once elvers were present, fishing effort within an individual river or geographic region tended to vary with fishing success. Consequently, daily (more accurately, nightly) catch $(\mathrm{kg})$, fishing effort $(\mathrm{h})$, and catch-perunit-fishing effort (CPUE; $\mathrm{kg} \cdot \mathrm{h}^{\cdot}$ ) distributions for each river, aggregated by fishery area, 

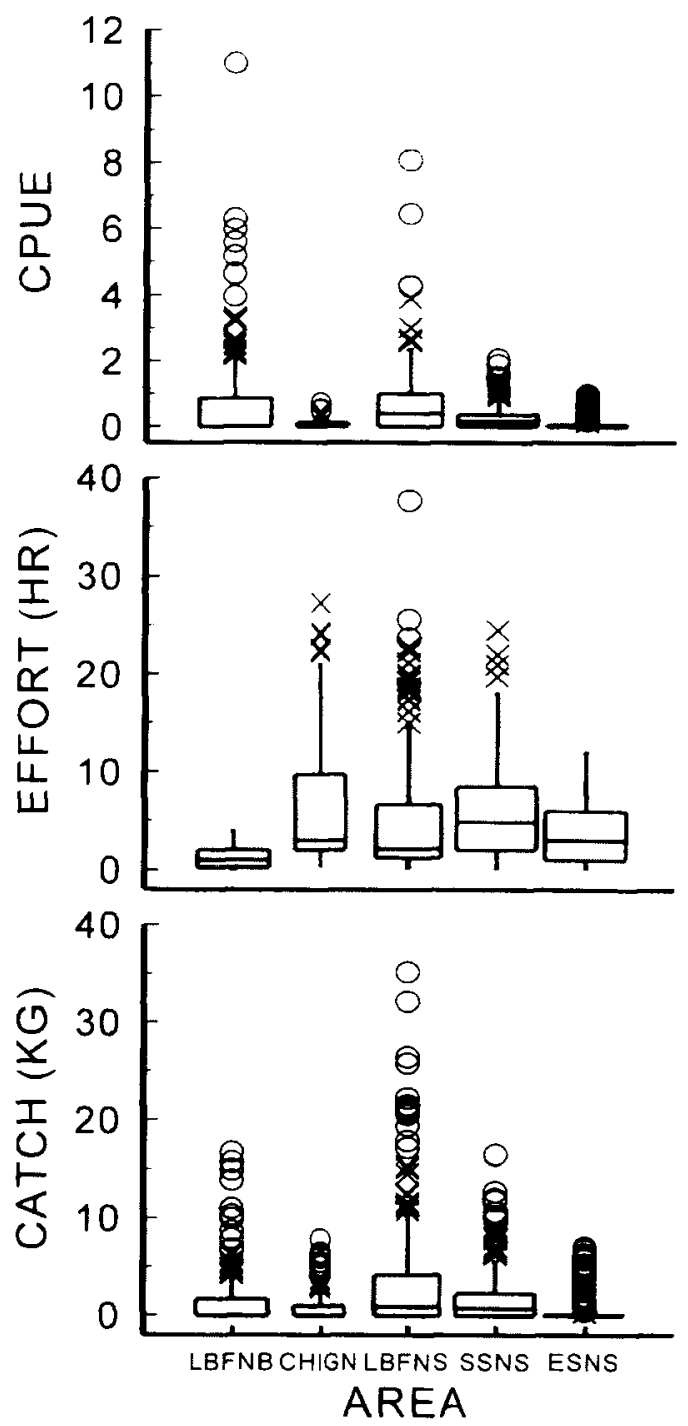

Figure 2

Box plots of American eel elver daily catch $(\mathrm{kg})$, dipnet fishing effort (h), and catch per unit effort (CPUE ; $\mathbf{k g}^{-h^{-1}}$ ) by geographic region (LBFNB - lower Bay of Fundy, N.B. ; CHIGNECTO - upper Bay of Fundy, N.B. and Chignecto Bay ; LBFNS - lower Bay of Fundy, N.S. ; SSNS - southern Atlantic coast of N.S. ; ESNS - eastern Atlantic coast of N.S.) in the Scotia-Fundy area of Atlantic Canada, 1996. The box contains the central $50 \%$ of values, the median is the central line within the box, and $x$ - and 0 -values represent outliers and far outliers.

Figure 2

Tracés en boîtes des prises quotidiennes de civelles $(\mathbf{k g})$, de l'effort de pêche à l'épuisette (h) et des prises par unité d'effort (PUE, $\mathrm{kg}^{-1} \mathrm{~h}^{-1}$ ), par région géographique (LBFNB = partie néo-brunswickoise de l'entrée de la baie de Fundy ; CHIGNECTO = partie néo-brunswickoise du fond de la baie de Fundy et baie de Chignecto ; LBFNS = partie néo-écossaise du fond de la baie de Fundy ; SSNS = côte atlantique sud de la Nouvelle-Écosse ; ESNS = côte atlantique est de la Nouvelle-Écosse) dans le secteur de Scotia-Fundy du Canada atlantique en 1996. La boîte contient le $50 \%$ central des valeurs, la médiane est la ligne centrale à l'intérieur de la boîte, et les valeurs $x$ et 0 représentent les cas aberrants et extrêmement aberrants. 
were highly right skewed and leptokurtic (Figure 2). The fishery statistics (catch, effort, CPUE), which include days of zero catch, are reported under the conditions of the fishing license and are believed accurate because of the high economic value of each license, the limited number of licenses, the active cooperation of fishers, and the stated low tolerance by fishery managers to serious license infractions. Catch statistics are inherently variable due to the variability in elver catchability and abundance (CASTELNAUD et al., 1994).

Dip-net fishing effort varied among five geographic regions from about $300 \mathrm{~h}$ to over $1700 \mathrm{~h}$ (Minas Basin was excluded because dip-net catches were inseparable from catches by other gear types). The elver catch by dip net totalled $1903 \mathrm{~kg}$ in $5204 \mathrm{~h}$ of fishing effort in these five geographic regions. Although daily elver catch $(\mathrm{kg})$ by dip net was significantly correlated with fishing effort $(h)$ among the five regions $\left(r_{\text {boot }}\right.$ ranged from 0.45 to $0.62, N$ ranged from 89 to $306, P=0.0002 ; B=5000$ replicates), the coefficients of determination $\left(r^{2}\right)$ of the relations ranged from 0.21 to 0.38 , implying that catch was not solely dependent on fishing effort. Randomization tests were used in all analyses because of the presence of one or more of the following conditions : small or differing sample sizes, unknown or highly right skewed and leptokurtic statistical distributions of variables, and significant $(P<0.0002)$ heterogeneity in regional CPUE variances (EDGINGTON, 1987).

The use of CPUE as an index of abundance (density) requires that catch rates be proportional to fish abundance. Although the relation between fish abundance and CPUE is biased when fish migrate through a local fishing zone because the ratio of CPUE to abundance depends on the duration of fishing and CPUE varies through the run (SAMPSON, 1991), such bias may be minor for this elver fishery because fishing activity occurs essentially throughout the elver run, and the catch and seasonal pattern of the fishery reflect the abundance and pattern of the elver run. Elvers spend a relatively short time transiting the fishing zone once hydrological conditions (river water temperature and level) reach levels conducive to upstream movement (CANTRELLE, 1981). Thus, the pattern of catch in the elver fishery was similar to, but lagged from, that by Irish-type elver traps (O'LEARY, 1971) located at the head of tide in the East River, Chester, (lag 1-3 d) located about midway along the South Shore (Figure 1) and the East River, Sheet Harbour, (lag 8-9 d) about midway along the Eastern Shore and about $140 \mathrm{~km}$ distant (JESSOP, 1997 ; unpublished data). Although the elver catch in the East River, Chester, was 1.3 times that in the East River, Sheet Harbour, the CPUE varied with elver run size ; the elver run was 3.3 times larger and the CPUE of the fishery was 3.4 times larger for the East River, Chester, than for the East River, Sheet Harbour. By geographic area, the total elver catch was 3.3 times larger and CPUE was 3.4 times larger for the fishery on the South Shore, where the East River, Chester is located, than on the Eastern Shore where the East River, Sheet Harbour is located. The positive correlations, for each of the five geographic regions, between CPUE and catch ( $r_{\text {bool }}$ from 0.67 to $0.93, N$ from 89 to 306 , all $P \leq 0.0002$; all $B=5000$ ) indicate that catch increases with increasing elver abundance (density) in each fishery. Thus, because the seasonal pattern and catch of the elver fishery mirrored the pattern and abundance of the elver run to two rivers in different geographic regions and CPUE and catch were correlated in all regions, it is plausible that the elver fishery reflects elver abundance within the remaining elver fishery regions.

Mean daily CPUE values differed significantly among regions (Table II ; randomization ANOVA, $P=0.0002, \mathrm{df}=41193 ; \mathrm{B}=5$ 000). Paired comparisons of mean $(95 \% \mathrm{Cl} ; \mathrm{B}=1000)$ dip-net CPUE differed significantly $(P=0.0002 ; \mathrm{B}=5000)$ between all but two of ten possible comparisons (LBFNB : LBFNS, $P=0.49$; CHIGNECTO : ESNS, $P=0.45$ ). The critical value used for Bonferroni adjustment of multiple pairwise comparisons was 0.005 . The substantial fishing effort in all regions, low correlation between catch and fishing effort, correlation between CPUE and catch, and significant differences in CPUE among regions support a conclusion of regional differences in elver abundance. 
Table II

Mean daily catch per unit of fishing effort (CPUE), with $95 \%$ confidence intervals (CI), by geographic region for the commercial elver dip-net fishery in the ScotiaFundy area of Atlantic Canada, 1996.

\section{Tableau II}

Prises moyennes quotidiennes par unité d'effort de pêche (PUE), par région géographique, de la pêche commerciale de la civelle à l'épuisette dans le secteur de Scotia-Fundy du Canada atlantique en 1996 (intervalles de confiance de $95 \%$ ).

\begin{tabular}{lcc}
\hline Region & CPUE & $95 \% \mathrm{Cl}$ \\
\hline Lower Bay of Fundy, N.B. (LBFNB) & 0.63 & $0.48-0.79$ \\
Chignecto (CHIGNECTO) & 0.07 & $0.05-0.09$ \\
Lower Bay of Fundy, N.S. (LBFNS) & 0.70 & $0.58-0.85$ \\
South Shore, N.S. (SSNS) & 0.27 & $0.23-0.31$ \\
Eastern Shore, N.S. (ESNS) & 0.08 & $0.06-0.10$ \\
\hline
\end{tabular}

The consistent regional variability in annual elver catches within the Scotia-Fundy area indicates regional differences in the coastal distribution of elvers. DEKKER (1986) reported variation in glass eel catches within the relatively small geographic area of Holland, CASTELNAUD et al. (1994) documented the geographic variability in elver catch along the Atlantic coast of France, while MORIARTY (1990) found substantial differences in annual elver catch through western and northern Europe as well as long-term changes in elver catch over a wide geographic area. The geographic distribution of elvers in the Scotia-Fundy area is generally reflected in the fishery for larger eels, where the largest fisheries occur in the Saint John River of southwest New Brunswick and along the southern Atlantic coast of Nova Scotia and smaller fisheries occur in the Chignecto Bay and Minas Basin areas of the upper Bay of Fundy and along the Eastern Shore of Nova Scotia (JESSOP, $1982 ; 1996 b)$.

The hypothesis that elver run size is proportional to river size (drainage area, discharge) within the Scotia-Fundy area was examined by correlation between the mean daily dip-net CPUE and river drainage area for those rivers (at least two rivers are represented from each region) where the total catch was by dip-net and fishing effort occurred on at least 20 days (mean $=39 \mathrm{~d}$, range $=22-67 \mathrm{~d}$ ). The lack of significant positive correlation (rboot $=0.50, N=19, P=0.51$, one-sided test ; $\mathrm{B}=5000$ ) may be explained by the obscuring effect of differing elver abundance among geographic regions and the possibility that elver catchability by dip-net may decrease with increasing river size (drainage area median $=149 \mathrm{~km}^{2}$, range $8-1833 \mathrm{~km}^{2}$ ). Additional evidence against the hypothesis that elver run size is proportional to river size and for a geographic difference in elver abundance is provided by the 1996 estimate of a run of 1124000 ( \pm 50000 ; $95 \% \mathrm{Cl}$ ) elvers, estimated from elver trap and commercial fishery catches, and density of 8400 elvers $\cdot \mathrm{km}^{2}$ to the East River, Chester (drainage area of $134 \mathrm{~km}^{2}$ ) on the South Shore of Nova Scotia and of 337000 ( $\pm 14000 ; 95 \% \mathrm{Cl}$ ) elvers and density of 640 elvers. $\mathrm{km}^{2}$ to the East River, Sheet Harbour (drainage area of $526 \mathrm{~km}^{2}$ ) on the Eastern Shore of N.S., (JESSOP, 1997). Within a region of similar coastal density of elvers, the elver run to a river may be proportional to its size but that hypothesis has not yet been tested.

Commercial quantities of elvers first arrive in estuarine waters in late April or early May, depending upon the area, peak in May (57-89\% of catch), and usually decline to low abundance in, or before, early-to-mid June (Figure 1). Small quantities of elvers (less than $1 \%$ of total catch) may continue to enter streams along the Atlantic coast and in the upper 
Bay of Fundy in early July and may continue into August in some Atlantic coast rivers (JESSOP, unpublished data). For the years 1994 to 1996, the proportion of the regional elver catch occurring in April increased from zero along the Eastern Shore of Nova Scotia to $29 \%$ (range $17 \%-43 \%$ ) along the South Shore then consistently declined along a route progressing into the lower Bay of Fundy, N.S. (25\%; range $9 \%-35 \%)$ and counter-clockwise through the upper Bay of Fundy from Nova Scotia ( $9 \%$; range $0 \%-17 \%)$ to New Brunswick ( $8 \%$; range $6 \%-11 \%$ ) and towards the lower Bay of Fundy, N.B. $(2 \%$; range $0.1 \%-4 \%$ ). During May, the proportion of regional elver catch increased to $67 \%$ (range 64\%-68\%) along the Eastern Shore, N.S., to $57 \%$ (range $46 \%-79 \%$ ) and $62 \%$ (range $33 \%-70 \%$ ) along the South Shore and lower Bay of Fundy, N.S., to $80 \%$ (range $71 \%-90 \%$ ) in Minas Basin and $83 \%$ (range $80 \%-89 \%$ ) in Chignecto Bay, and $89 \%$ (range $88 \%-92 \%$ ) in the lower Bay of Fundy, N.B. June catches declined in a similar pattern from $33 \%$ (range $31 \%-36 \%$ ) along the Eastern Shore to $9 \%$ (range $8 \%-10 \%$ ) in the lower Bay of Fundy, N.B.

\section{OCEANOGRAPHIC EFFECTS ON ELVER DISTRIBUTION}

Although surveys have established the presence of larvae of the American eel in the Gulf Stream offshore of Nova Scotia (TESCH, 1977 ; MCCLEAVE, 1993), no surveys have examined the distribution or survival of larvae/glass eels on the continental shelf as they transit this region before entering coastal waters. Annually, variable biological (oceanic food supply, predation) and oceanographic (oceanic and coastal water currents and temperatures) conditions may govern larval oceanic survival and distribution on a continental and regional scale (MCCLEAVE, 1993). Thus, the Gulf Stream advects American eel leptocephali north and east from their hatching area in the Sargasso Sea to areas off the Atlantic coast of North America ; specifically, off the coast of the Maritime Provinces. American eel elvers are hypothesized (KLECKNER and MCCLEAVE, 1985 ; MCCLEAVE, 1987) to detrain actively from the Gulf Stream aided by the oceanographic processes of diffusion and the intrusion of eddies and warm-core rings of Gulf Stream water into the slope water off the continental shelf. These meanders and loops increase the path length and reduce net current speed of the Gulf Stream off the New EnglandMaritime Provinces coast and may allow elvers to more actively move into slope waters before being carried further northeast. Leptocephali that are ontogenetically ready then metamorphose into glass elvers, perhaps when the sea bottom over the shallow continental shelf is encountered, change their behaviour from a diel vertical rhythm to a tidal rhythm, and move shoreward via selective tidal stream transport in a process similar to that used in estuarine waters (MCCLEAVE and KLECKNER, 1982). The relative contribution to shoreward movement played by active swimming is uncertain and the average swimming speed is unknown. The negative buoyancy of glass eels may assist in taking advantage of shoreward moving bottom currents but requires swimming activity for depth maintenance (HICKMAN, 1981).

Off Nova Scotia, Gulf Stream surface currents flow about $85 \mathrm{~km} \cdot \mathrm{d}^{-1}$ to the eastnortheast (WORTHINGTON, 1976), with the northern edge of the Gulf Stream about $490 \mathrm{~km}$ (range $350-620 \mathrm{~km}$ ) offshore at the southern end of Nova Scotia and $625 \mathrm{~km}$ (range 375-775 km) offshore at the northern end (DRINKWATER et al., 1994 ; Figure 3). The shelf-slope front (the narrow boundary separating the cool shelf waters from the warmer slope waters offshore of the continental shelf) is about $100 \mathrm{~km}$ closer to the southwest coast (South Shore) than to the northeast coast (Eastern Shore) of Nova Scotia. Off the southern tip of Nova Scotia, the continental shelf (Scotian Shelf) is about $130 \mathrm{~km}$ wide, increasing to $240 \mathrm{~km}$ wide off Cape Breton, with depths averaging less than $200 \mathrm{~m}$ and less than $100 \mathrm{~m}$ over many banks. The positions of the Gulf Stream, shelf/slope front, and Scotian Shelf make it potentially easier for elvers to come inshore along the southwest rather than along the northeast coast, assuming that oceanographic conditions are equal throughout the area. 


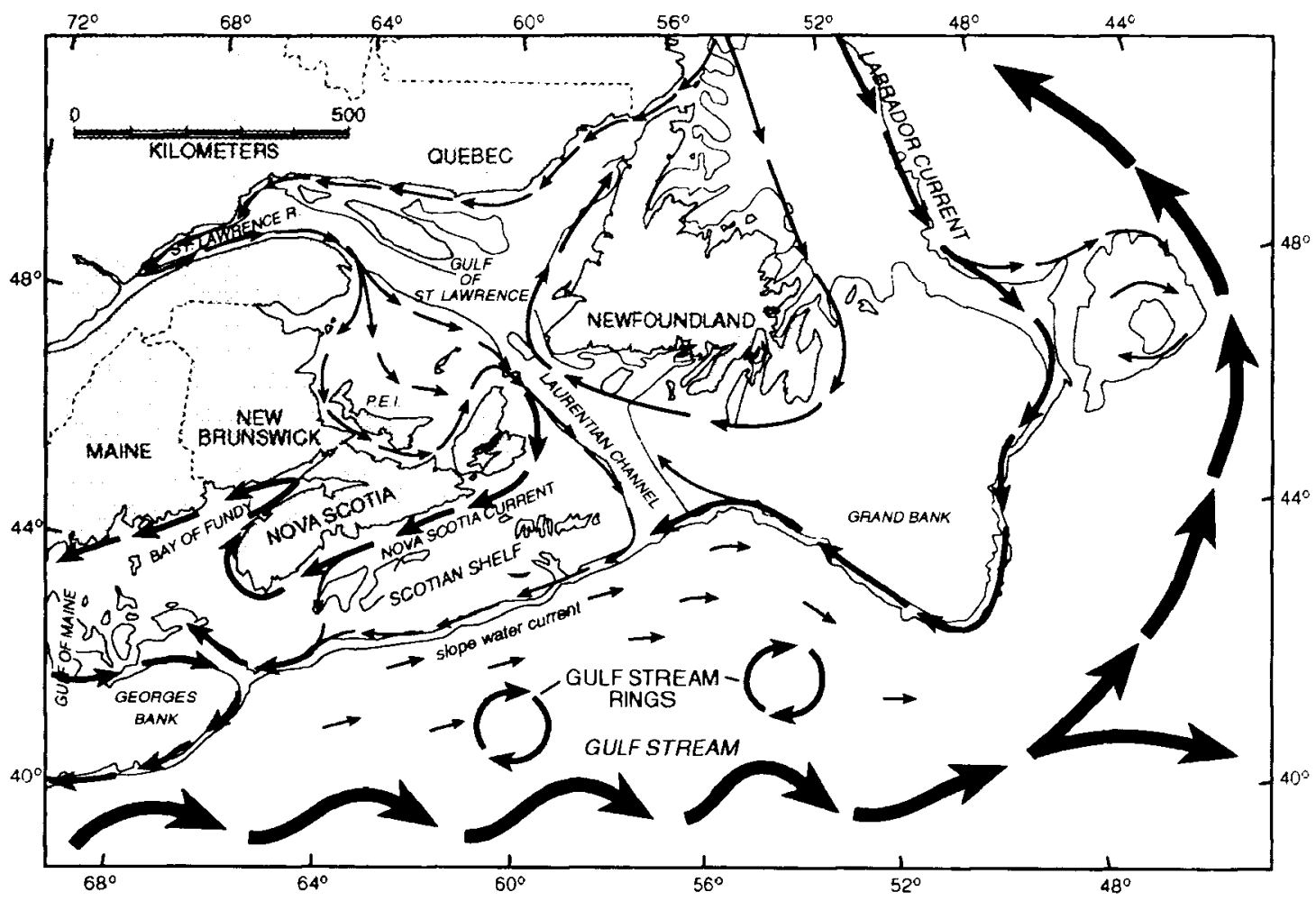

Figure 3

Map of Atlantic Canada showing the major oceanographic surface currents and bottom features within the continental shelf. The thickness of lines indicating the currents is proportional to current strength.

Figure 3

Carte du Canada atlantique illustrant les grands courants océanographiques de surface et les caractéristiques du fond sur le plateau continental. L'épaisseur des lignes représentant les courants est proportionnelle à la force de ces derniers.

However, oceanographic conditions between the Gulf Stream and the coast are complex, with important seasonal changes in salinity, temperature, and currents, particularly over the Scotia Shelf and in the Gulf of Maine and Bay of Fundy (HACHEY et al., 1954 ; SUTCLIFFE et al., 1976 ; DRINKWATER et al., 1979, 1994 ; SMITH 1983, 1989). The region from the Gulf of St. Lawrence to the Gulf of Maine inclusive may be considered as an oceanographic system in which some events occurring as far south as the Gulf of Maine are linked to annual freshwater discharge from the Gulf of St. Lawrence (SUTCLIFFE et al., 1976 ; DRINKWATER et al., 1979 ; SMITH, 1989). The waters of the Scotian Shelf are a mixture of low salinity water from the Gulf of St. Lawrence (via the Nova Scotia Current) and slope water, which is in turn a mixture of waters from the warm Gulf Stream, the North Central Atlantic, and the cold Labrador Current (HACHEY, 1954).

Given the known and hypothesized effects of oceanic conditions on larval eel transport and survival (MCCLEAVE, 1987, 1993 ; CASTONGUAY et al., 1994) and of tidal conditions in estuaries (MCCLEAVE and KLECKNER, 1982), it is plausible that oceanographic features could contribute to the greater observed elver abundance in the South Shore and lower Bay of Fundy areas of Nova Scotia than in the Eastern Shore area of Nova Scotia. Firstly, warm-core eddy activity by the Gulf Stream is more 
active southwest of (west of about 63. W ; DRINKWATER et al., 1996) than northeast of Halifax, which is roughly midway along the Atlantic coast of Nova Scotia. Warm-core eddies tend to move southwest while embedded in the slope water, which moves northeast at about $4 \mathrm{~km} \cdot \mathrm{d}^{\prime}$ (SMITH and PETRIE, 1982). Secondly, after transiting the shelf edge to the Scotian Shelf, elvers in near-surface waters would encounter the offshore branch of the Nova Scotia Current which moves southwest at less than $1 \mathrm{~km} \cdot \mathrm{d}^{-1}$. However, elvers remaining near bottom over the Scotian Shelf (according to the behavioural hypothesis proposed by KLECKNER and MCCLEAVE (1985) and MCCLEAVE (1987)) could utilize a deep shoreward current of about $2 \mathrm{~km} \cdot \mathrm{d}^{\cdot 1}$ associated with a surface offshore drift (LAUZIER, 1967) to move towards the coast. Inshore current movement is particularly strong in the deeper channel waters between the Emerald and LaHave Banks south of Halifax and through the Northeast Channel between the Scotian Shelf and Georges Bank (SMITH and PETRIE, 1982 ; SMITH, 1989) although inflow of slope water through the Northeast Channel into the Gulf of Maine varies seasonally and is minimal in spring (RAMP et al., 1985). Thirdly, about $50 \mathrm{~km}$ off the coast, elvers would encounter the seaward edge of the $30 \mathrm{~km}$ wide inshore branch of the low salinity Nova Scotia Current which flows southwest at about $6 \mathrm{~km} \cdot \mathrm{d}^{\prime}$ then continues past Cape Sable and into the Gulf of Maine, particularly during late winter and early spring when elvers are actively moving inshore, mixing with water from the Gulf of Maine before flowing north along the eastward side of the lower Bay of Fundy, (SUTCLIFFE et al., 1976 ; SMITH, 1989). The Scotian Shelf progressively shallows, from about $200 \mathrm{~m}$ at $50 \mathrm{~km}$ offshore to $100 \mathrm{~m}$ at $20 \mathrm{~km}$ and $50 \mathrm{~m}$ at $10 \mathrm{~km}$ offshore, and the inshore Nova Scotia Current extends to the bottom through much of its width. Although elvers swim at speeds greater than $10 \mathrm{~cm} \cdot \mathrm{s}^{-1}$ for at least short distances (BARBIN and KRUEGER, 1994), elvers maintaining a reputedly optimal swimming speed of one body length per second (WEIHS, 1973 ; HICKMAN, 1981) or about $6 \mathrm{~cm} \cdot \mathrm{s}^{-1}\left(5 \mathrm{~km} \cdot \mathrm{d}^{-1}\right.$; Scotia-Fundy elvers average about $58 \mathrm{~mm} \mathrm{TL}$ ), could be advected perhaps $40 \mathrm{~km}$ (or by perhaps $120 \mathrm{~km}$ at $2 \mathrm{~cm} \cdot \mathrm{s}^{-1}$ ) to the southwest while transiting this zone of the Scotia-Shelf.

The observed high-to-moderate elver densities in the lower Bay of Fundy, N.S. and N.B., regions and the May peak in elver abundance in the lower Bay of Fundy, N.B. area are consistent with the residual currents circulating counter-clockwise around the Bay of Fundy (GREENBURG, 1984). American shad (Alosa sapidissima) migrating through the Bay of Fundy also follow the counter-clockwise path of the residual current (DADSWELL et al., 1987). The low elver densities in the Minas Basin and Chignecto Bay areas of the upper Bay of Fundy may result from their position off the main current path and turbulent tidal flushing. Early elver arrivals to the lower Bay of Fundy may progress around the Bay until water temperatures rise sufficiently to cue river entrance (MARTIN, 1995).

A geographic cline in elver run timing may be linked to differences in coastal and stream water temperatures. Inshore coastal water temperatures increased, between April and June, from west (South Shore) to east (Eastern Shore) atong the Atlantic coast of Nova Scotia (WALKER et al., 1986). Sea temperatures of $4{ }^{\circ} \mathrm{C}$ were first recorded during late April off the South Shore area, about mid-May in the Halifax area, midway along the coast, and early-to-mid June in the northeastern portion of the Eastern Shore area. Coastal waters in the Bay of Fundy are warmer in winter and early spring at the mouth than at the head of the Bay with a reversal occurring by summer (GREENBURG, 1984).

Elvers may occur inshore waters for weeks or even months before they actively enter a stream (HARO and KRUEGER, 1988). The time difference between elver arrival in estuarine waters and the start of upstream movement may reflect both a physiological adjustment period preparatory to entering freshwater $(\mathrm{TESCH}, 1977)$ and timing of the cue to begin upstream movement provided by rising water temperatures and falling water levels (HARO and KRUEGER, 1988 ; MARTIN, 1995). Rivers usually warm sooner and 
spring runoff begins earlier along the south shore of Nova Scotia and lower Bay of Fundy shore than elsewhere in the Scotia-Fundy area (DZIKOWSKI, 1984), consistent with the stream entrance of elvers during mid-to-late April along the South Shore and lower Bay of Fundy shores of Nova Scotia and early-to-mid May along the Eastern Shore, N.S. In 1996, mean daily water temperatures in the East rivers, Chester and Sheet Harbour (located in the central portion of the Atlantic coast of Nova Scotia about $140 \mathrm{~km}$ apart) first reached $10{ }^{\circ} \mathrm{C}$ on similar dates (May 5-7) but the first elver fishery catches occurred in tidal waters on April 27 (versus May 26) and the first peak in elver trap catches occurred at, or just upstream of the tidal limit, on May 18 (versus June 5) in the more southerly East River, Chester (JESSOP, 1997). Although river water temperatures and discharge may act as gating factors to elver upstream movement, the timing of elver arrival inshore, is likely controlled by oceanographic conditions, which may vary regionally.

\section{CONCLUSIONS}

The elver fishery of the Scotia-Fundy area of Nova Scotia and New Brunswick has grown substantially in the past four years but may now have neared its limit because of the controls placed on the existing fishery. Future growth may depend on extension of the fishery to new areas or to reduced restriction in existing areas. The fishery has provided valuable insight into the seasonal and regional distribution of elver abundance and, in future, may reveal the degree of natural variability in elver abundance both annually and regionally within the Maritime Provinces.

\section{ACKNOWLEDGEMENTS}

I thank B. PETRIE for information and insight into the oceanographic processes of the Scotian Shelf area and for reviewing a draft manuscript.

\section{REFERENCES}

BARBIN G.P., KRUEGER W.H., 1994. Behaviour and swimming performance of elvers of the American eel, Anguilla rostrata, in an experimental flume. J. Fish Biol., 45, 111 121.

CANTRELLE I., 1981. Etude de la migration et de la pêche des civelles Anguilla anguilla L. 1758 dans l'estuaire de la Gironde. Thèse de doctorat de 3ème cycle, Univ. Paris VI, $237 \mathrm{p}$.

CAstelnaud G., guerault D., Desaunay Y., EliE P., 1994. Production et abondance de la civelle en France au début des années 90. Bull. Fr. Pêche Piscic., 335, 263-287.

CASTONGUAY M., HODSON P.V., MORIARTY C., DRINKWATER K.F., JESSOP B.M., 1994. Is there a role of ocean environment in American and European eel decline ? Fish. Oceanogr., 3, 197-203.

DADSWELL M.J., MELVIN G.D., WILLIAMS P.J., THEMELIS D.E., 1987. Influences of origin, life history, and chance on the Atlantic coast migration of American shad. Amer. Fish. Soc. Symp., 1, 313-330.

DEKKER W., 1986. Regional variation in glass eel catches and evaluation of multiple sample sites. Vie Milieu, 36, 251-254.

DRINKWATER K., PETRIE B., SUTCLIFFE W.H. Jr., 1979. Seasonal geostrophic volume transports along the Scotia Shelf. Estuarine Coastal Mar. Sci, 9, 17-27. 
DRINKWATER K.F., MYERS R.A., PETTIPAS R.G., WRIGHT T.L., 1994. Climatic data for the Northwest Atlantic : the position of the Shelt/Slope front and the northern boundary of the Gulf Stream between $50^{\circ} \mathrm{W}$ and $75^{\circ} \mathrm{W}, 1973-1992$. Can. Data Rep. Hydrogr. Ocean Sci., 125, 103 p.

DRINKWATER K.F., COLBOURNE E., GILBERT D., 1996. Overview of environmental conditions in the Northwest Atlantic in 1994. NAFO Sci. Coun. Studies, 25, 25-58.

DZIKOWSKI P., 1984. Agroclimatic atlas. Nova Scotia Dept. of Agriculture and Marketing, Halifax, Nova Scotia, Agdex No. 070, 30 p.

EDGINGTON E.S., 1987. Randomization tests. Marcel Dekker, New York, 340 p.

FAHAY M.P., 1978. Biological and fisheries data on American eel, Anguilla rostrata (Le Sueur). Northeast Fisheries Center, Nat. Mar. Fish. Serv. Tech. Ser. Rep. No. $17,77 \mathrm{p}$.

GOUSSET B., 1992. Eel culture in Japan. Bull. de l'Inst. océanogr., n' spécial 10, Monaco, $1-128$.

GREENBURG D.A., 1984. A review of the physical oceanography of the Bay of Fundy. In GORDON D.C. Jr. and DADSWELL M.J. (eds.), Update on the marine environmental consequences of tidal power development in the upper reaches of the Bay of Fundy, Can. Tech. Rep. Fish. Aquat. Sci. No. 1256, 9-30.

HACHEY H.B., HERMANN F., BAILEY W.B., 1954. The waters of the ICNAF convention area. Int. Comm. Northwest Atl. Fish. Annu. Proc., 1953-54, 4, 67-102.

HARO A.J., KRUEGER W.H., 1988. Pigmentation, size, and migration of elvers (Anguilla rostrata (Le Sueur)) in a coastal Rhode Island stream. Can. J. Zool., 66, 25282533.

HICKMAN R.A., 1981. Densities and swimbladder development of juvenile American eels, Anguilla rostrata (Le Sueur) as related to energetics of migration. J. Fish. Biol., 18, 507-517.

JESSOP B.M., 1982. A review of the status and management of commercial fisheries for American eels (Anguilla rostrata) in the Maritime Provinces. In Loftus K.H. (ed.), Proc. N. Amer. Eel Conf., Ont. Min. Nat. Res., Ont. Fish. Tech. Rep. Ser., 4, 28-31.

JESSOP B.M., 1995. Justification for, and status of American eel elver fisheries in ScotiaFundy Region. DFO Atl. Fish. Res. Doc., 95/2, 10 p.

JESSOP B.M., 1996a. Review of the American eel elver fisheries in Scotia-Fundy area, Maritime Region. DFO Atl. Fish. Res. Doc., 96/04, 7 p.

JESSOP B.M., 1996b. The status of American eels Anguilla rostrata in the Scotia-Fundy area of the Maritime Region as indicated by catch and license statistics. DFO Atl. Fish. Res. Doc., 96/118, 15 p.

JESSOP B.M., 1997. The biological characteristics of, and efficiency of dip-net fishing for, American eel elvers in the East River, Chester, Nova Scotia. DFO, Halifax, N.S., Doc. No. 97-01, 29 p.

KLECKNER R.C., MCCLEAVE J.D., 1985. Spatial and temporal distribution of American eel larvae in relation to North Atlantic Ocean current systems. Dana, 4, 67-92.

LAUZIER L.M., 1967. Bottom residual drift on the Continental Shelf area of the Canadian Atlantic Coast. J. Fish. Res. Board Can., 24, 1845-1858.

MARTIN M.H., 1995. The effects of temperature, river flow, and tidal cycles on the onset of glass eel and elver migration into freshwater in the American eel. J. Fish Biol., 46, 891-902.

MCCLEAVE J.D., 1987. Migration of Anguilla in the ocean : signposts for adults ! Signposts for leptocephali? In HERRNKIND W.F. and THISTLE A.B. (eds.), Signposts in the sea, Florida State Univ., Tallahassee, Fla., 102-107. 
MCCLEAVE J.D., 1993. Physical and behavioural controls on the oceanic distribution and migration of leptocephali. J. Fish Biol., 43, 243-273.

MCCLEAVE J.D., KLECKNER R.C., 1982. Selective tidal stream transport in the estuarine migration of glass eels of the American eel (Anguilla rostrata). J. Cons. int. Explor. Mer, 40, 262-271.

MORIARTY C., 1990. European catches of elver of 1928-1988. Int. Revue ges. Hydrobiol., $75,701-706$.

O'LEARY D.P., 1971. A low head elver trap developed for use in Irish rivers. In McGrath C.J. (ed.), EIFAC Tech. Pap. 14, 129-133.

RAMP S.R., SCHLITZ R.J., WRIGHT W.R., 1985. The deep flow through the Northeast Channel, Gulf of Maine. J. Phys. Oceanogr., 13, 1034-1054.

SAMPSON D.B., 1991. Local catch per unit of effort as an index of global fish abundance. In COWX I.G. (ed.), Catch effort sampling strategies: their application in freshwater fisheries management, Fishing News Books, Oxford, 275-284.

SHELDON W., 1974. Elvers in Maine. Techniques of locating, catching and holding. State of Maine, Dept. of Marine Resources, $25 \mathrm{p}$.

SMITH P.C., 1983. The mean and seasonal circulation off southwest Nova Scotia. J. Phys. Oceanogr., 13, 1034-1054.

SMITH P.C., 1989. Seasonal and interannual variability of current, temperature and salinity off southwest Nova Scotia. Can. J. Fish. Aquat. Sci., 46 (Suppl. 1), 4-20.

SMITH P.C., PETRIE B.D., 1982. Low-frequency circulation at the edge of the Scotian Shelf. J. Phys. Oceanogr., 12, 28-46.

SUTCLIFFE W.H. Jr., LOUCKS R.H., DRINKWATER K.F., 1976. Coastal circulation and physical oceanography of the Scotia Shelf and the Gulf of Maine. J. Fish. Res. Board Can., 33, 98-115.

TESCH F.W., 1977. The eel : biology and management of Anguillid eels. Chapman and Hall, London, $434 \mathrm{p}$.

WALKER R.E., DOBSON D., STEAD P., 1986. Long-term temperature monitoring program 1985 : Scotia-Fundy, Gulf of St. Lawrence, and Newfoundland. Can. Data Rep. Hydrog. and Ocean Sci., No. 49, 521 p.

WEIHS D., 1973. Optimal fish cruising speed. Nature, 245, 48-50.

WORTHINGTON V., 1976. On the North Atlantic circulation. The Johns Hopkins Univ. Press, Baltimore, MD, $110 \mathrm{p}$. 